\title{
Shear Walls Induced RC Structures
}

\author{
Kesava Rao B ${ }^{1}$, Dr. R. Chandramohan², G. Sanijya ${ }^{3}$, Y. Naga Mahesh ${ }^{4}$ \\ ${ }^{12}{ }^{4}$ Department of Civil Engineering, RVR \& JC College of Engineering, Guntur-522 019, India \\ kesava.battena@gmail.com ${ }^{1}$
}

Article History: Received: 10 November 2020; Revised: 12 January 2021; Accepted: 27 January 2021; Published online: 05 April 2021

\begin{abstract}
In recent years, the construction of skyscrapers has been on the rise to overcome the shortage of land. These buildings are subject to an external lateral force, such as an earthquake and wind pressure. Pushover analysis (POA) has been broadly used in predicting the earthquake response of structures, and shear walls have been shown to be lateral drag elements. Therefore, in the present work, the effect of placing a shear wall on the periphery symmetrically, the periphery asymmetrically and in the center of the building is performed using the ETABS software. Using the response spectrum methodand thetime history method, a dynamic analysis is performed. Responses such as floor shear, floor displacement, and lateral floor shifts due to seismic forces are evaluated for various locations of the shear wall. According to the results and analysis, the shear wall on the symmetrical periphery of the structure is reducing the displacement and deviation of the floor compared to other cases.
\end{abstract}

Keywords: Pushover Analysis, Response Spectrum Method, Shear Wall, High Rise Building, Earthquake Response

\section{Introduction}

The need for shelter for densely populated cities or urban area, where land cost is more and additional horizontal extension is not possible due to lack of space availability, so the only solution is vertical extension. A Multi-store is a building that has several floors above the ground surface. Multi-storey building structures purposeis to increase the surface of the building structures without using any additional area of the land on which the building is built, thus saving land and money in most cases (depending on the material used and the prices of the land in the area). The design procedureof multi-storey building structures requires not only imaginings and conceptual thinking, but also a good understanding of the science of structural engineering, as well as facts of practical features such as recent design codes, laws, etc. The purpose of the standards is to ensure and improve safety while maintaining a careful balance between economy and safety (Epackachi et al., 2015, Hitaka T and Matsui C. 2003, Jalali and F. Dashti. 2010)

Tall structures face enormous loading effects due to dominant lateral forces (Hamdy H. A and Abd-el-rahim, 2010, A Murali Krishna and E Arunakanthi. 2014, Hu H and Nie J. 2013, M.Pavani et al., 2015). The main lateral forces are seismic forces and wind loads. When designing tall buildings, strength, practicality, steadiness and person comfort and human comfort must be taken into account. Earthquake is one of the most hazardous natural hazard and is causing significant damage to structures (Su RK and Wong S.M. 2007).

The forces of earthquakes are the most dangerous dangers that cause loss of money and life. Damage or loss is not only due to vibrations, also due to landslides, floods, tsunamis, etc., occur at the time of the earthquake. Next, it is a very fundamental need to design the structure to withstand moderate to very high seismic movements, depending on the area of the site and the type of structure. When designing structures, most researchers and engineers use equivalent static and dynamic analyzes. An equivalent static method is adopted to design the structure up to 90 meters high, the dynamic analysis method is used to design more than 90 meters. Dynamic analysis will require some sort of direct response spectrum analysis.

In the current research, the $G+10$ multi-storey facility in Guntur, India is analyzed and designed using ETABS software. Models of larger and more complex buildings, which includes a broad variety of nonlinear behaviors, make the tool of option for structural engineers in the construction industry.

To design the building components (Slabs, Beams, Columns and Bases) and first of all, it is significant to acquire the plan of the particular selected building, i.e. the location of the particular rooms (living room, bedroom, kitchen, bathroom, etc.), from in ways that serve their respective purposes and are also tailored to people's needs and comforts. The building structure plan is drawn using AutoCAD software. Therefore, depending on the appropriateness; the arrangement of the beams and the position of the columns are fixed. Then the loads or dead loads are calculated, which influenced by the unit weight of the materials used (concrete, 
bricks) and the moving loads, which according to the IS code: 456-2000 and the HYSD Fe 415 bars according to IS: 1786-1985. For the design of beams and columns it is essential to know the moments to which they are subjected. For this, frame analysis is performed using the limit state method. This study is the key reaction of the building's shear walls.

The walls are built vertically continuous, which can provide good sound and fire controllers between apartments. At the same time, they are suitable for structural planning. These walls can often be used for lateral force resistances. The main purposes of shear walls are to provide symmetry in the stiffness, tension stability and overturning ability of the foundation.

\section{Earthquake design philosophy}

The philosophy of seismic design Figure - 1 can be summarized as follows,

(i) In case of minor but frequent impacts, the main elements of the building that support the horizontal and vertical forces should not be damaged. However, non-load-bearing construction parts can suffer repairable damage.

(ii) In the event of moderate but occasional impacts, the main elements may suffer repairable damage, while the other extra parts of the building may also be damaged to such an extent that they even have to be replaced after the earthquake; In severe but rare shakes, the main members can be severely damaged and the building should not failed or collapse.

\section{Shear wall}

The shear wall is a structural element, which is also used to resist lateral forces, i.e. parallel to the plane of the wall. Reinforced concrete (RC) buildings often have vertical plate-shaped reinforced concrete walls called shear walls, as well as slabs, beams and columns (Lee and Mosalam 2005). These walls normally start at the level of the foundation and are uninterrupted throughout the height of the building. Shear walls are frequently provided for the length and width of the buildings. Shear walls are like wide vertically oriented beams that carry seismic loads to the foundations of buildings.

Most CR buildings with shear walls also have columns; These columns mainly support gravity loads (i.e. those due to the building's own weight and contents). Shear walls provide high strength and rigidity to buildings in the path of their direction, which considerably reduces the lateral swing of the building and thus diminish damage to the building structure and its contents. The shear walls should preferably be positioned in length and width (Mallika.K and Nagesh Kumar.G. 2016, Shruti Badami. and M. R. Suresh. 2014, Axay Thapa and Sajal Sarkar. 2017). However, if they are planned in one direction only, it is essential to provide a suitable grid or network of columns and beams in the vertical plane (moment resistant frame) along the other direction to resist the effects of strong earthquakes. Shear walls in buildings must be placed symmetrically on the plane to reduce the damaging effects of torsion in buildings. They could be placed symmetrically along one or both directions in plan. The shear walls are oblong in cross section, as shown in Figure-2, that is, one cross section size is much larger than the other. Although the rectangular cross section is common, L and $\mathrm{U}$ shaped sections are also used [11-13]. The thin-walled RC hollow shafts around the elevator core of buildings also act as shear walls and must be harnessed to withstand seismic forces (Sylviya. B and P. Eswaramoorthi. 2018, MD. Maksudul Haque and Md. Hasibulhasan Rahat. 2018, Lee T. H and Mosalam K. M. 2005, Nguyen N. H and Whittaker A. S. 2017, Smith B.J., Kurama Y.C and McGinnis M.J. 2013).

The present work has as its objective a goal of the behavior of the structure before the earthquake and the location of the shear walls that provide greater stability and safety to the structure. The building considered for study in this project is a reinforced concrete moment resistant frame building designed for gravity loads and seismic loads. The structure is evaluated according to the seismic code IS 1893: 2002 by linear static analysis and dynamic analysis using the ETABS software. 


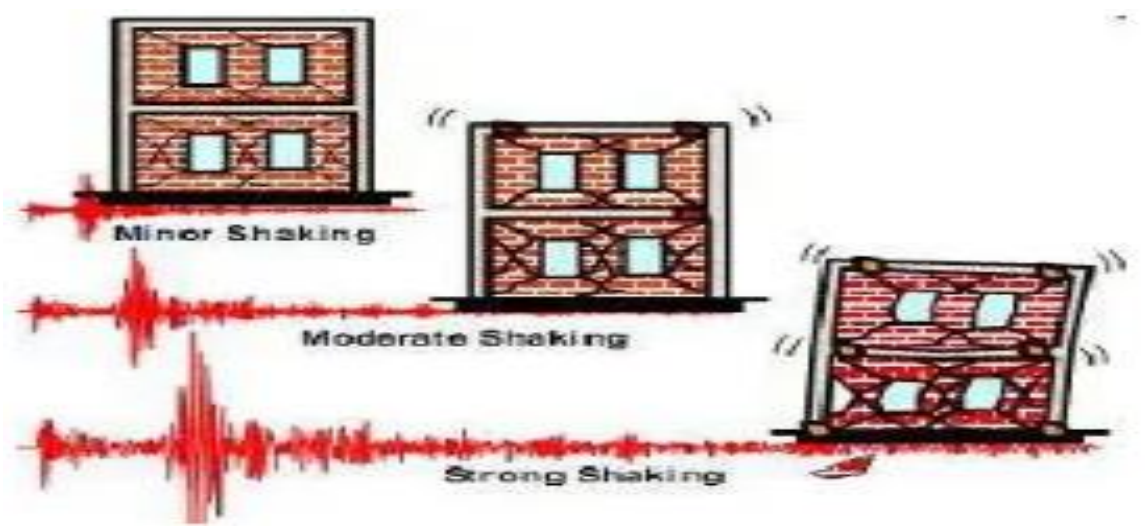

Figure-1. Earthquake phenomena

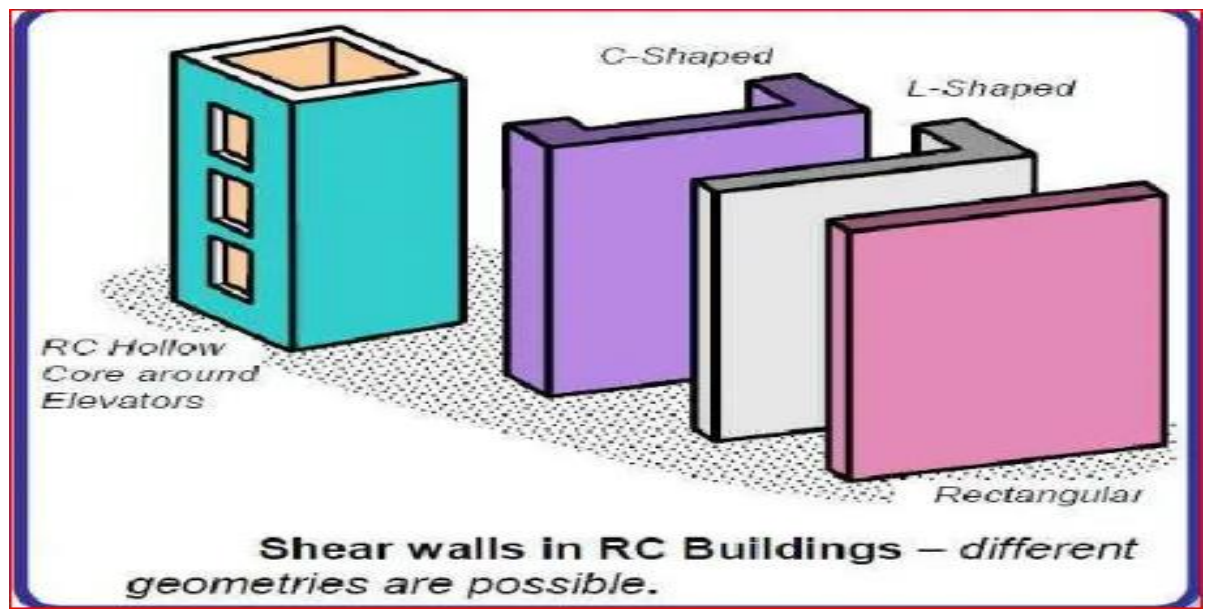

Figure 2. Geometry of shear wall

(Belsari., et al 2020)

\section{Modelling and Method}

For the purposes of the analysis, the RC structure $(\mathrm{G}+10)$ of the plants and a plant area of $32.3 \mathrm{~m} \times 20.72 \mathrm{~m}$ found in Guntur, India was selected. The height from the ground to the plant is $3 \mathrm{~m}$ and the ceiling height is $3 \mathrm{~m}$. The grade of concrete used is M30 and for structural steel it is Fe 415.

The structural data of the building and the design variables for the analysis are reported in Table 1 and Table 2 respectively. A mode shape is a specific pattern of vibration executed by a mechanical system at a specific frequency. Different mode shapes will be associated with different frequencies.

Model 1 is a structure in approx without shear wall and the corresponding Plan, 3D view and mode shapes are shown in Figure 3. In Model 2, the shear wall located near the core of the structure and the corresponding plan, 3D view and mode shapes are shown in Figure 4, the shear wall of model 3 located on the periphery of the structure symmetrically and the corresponding Plan, 3D view and mode shapes are shown in Figure 5, and the shear wall of Model 4 located in the outer position of the structure asymmetrically and the corresponding plan, 3D view and mode shapes are shown in Figure 6.

Table 1. Structural data

\begin{tabular}{|l|l|}
\hline Description & Information \\
\hline Size of Primary Beams & $380 \mathrm{~mm} \times 450 \mathrm{~mm}$ \\
\hline Size of Secondary Beams & $300 \mathrm{~mm} \times 300 \mathrm{~mm}$ \\
\hline Size of Columns & $460 \mathrm{~mm} \times 460 \mathrm{~mm}$ \\
\hline Building Height & $33 \mathrm{~m}$ \\
\hline Storey Height & $3 \mathrm{~m}$ \\
\hline
\end{tabular}




\begin{tabular}{|l|l|}
\hline No. of storey above ground floor & 10 \\
\hline Type of Structure & RC frame \\
\hline Horizontal floor System & Beams and slabs \\
\hline Grade of Concrete & M30 \\
\hline Grade of steel & Fe 415 \\
\hline Software Used & ETABS 17 \\
\hline
\end{tabular}

Table 2. Design variables for analysis

\begin{tabular}{|l|l|}
\hline Design Variable & Value \\
\hline Dead loads & \\
\hline a) Brick masonry & $20 \mathrm{kN} / \mathrm{m}^{2}$ \\
b) Concrete & $25 \mathrm{kN} / \mathrm{m}^{2}$ \\
\hline Live loads & \\
\hline a) Floor load & $02 \mathrm{kN} / \mathrm{m}^{2}$ \\
b) roof load & $1.5 \mathrm{kN} / \mathrm{m}^{2}$ \\
\hline Wall loads & $18 \mathrm{kN} / \mathrm{m}$ \\
a) Outer Walls & $14 \mathrm{kN} / \mathrm{m}$ \\
b) Inner Walls & 1 \\
\hline Importance Factor & 0.36 \\
\hline Zone Factor & 5 \\
\hline Response Reduction Factor & \\
\hline
\end{tabular}

\section{Results and Discussion}

Linear static analysis and Response spectrum analysis under gravity and seismic loads were performed on all four models by using ETABS software. Linear analysis-based results are shown in Figure 7 and Figure 8 and its indicates the displacements of the each storey in X and Y directions, respectively as indicted in Model 1 to 4 . Based on the results observed that model 4 storey displacements are minimum and model 1 have maximum storey displacements. The variation in minimum to maximum displacement between model 4 and Model 1 is about $40 \%$.

Similarly, for response spectrum curve is shown in Figure 9. and analysis are shown in Figure 10 and 11. Figure 10 and Figure 11 indicates the displacements of the each storey in $\mathrm{X}$ and $\mathrm{Y}$ directions, respectively as indicated in Model 1 to 4 . Based on the results observed that model 4 storey displacements are minimum and model 1 have maximum storey maximum displacement between model 4 and Model 1 is about $44 \%$. The lateral displacement in X- Y direction of structures for Storey 01 to Storey 11 is shown in Table 3.

Table 3. Lateral displacements of structures

\begin{tabular}{|l|c|c|c|c|c|c|c|c|}
\hline & \multicolumn{3}{|c|}{ Displacement in X-direction } & \multicolumn{3}{c|}{ Displacement in Y-direction } \\
\hline Storey & $\begin{array}{c}\text { Model 1 } \\
(\mathrm{mm})\end{array}$ & $\begin{array}{c}\text { Model 2 } \\
(\mathrm{mm})\end{array}$ & $\begin{array}{c}\text { Model 3 } \\
(\mathrm{mm})\end{array}$ & $\begin{array}{c}\text { Model 4 } \\
(\mathrm{mm})\end{array}$ & $\begin{array}{c}\text { Model 1 } \\
(\mathrm{mm})\end{array}$ & $\begin{array}{c}\text { Model 2 } \\
(\mathrm{mm})\end{array}$ & $\begin{array}{c}\text { Model 3 } \\
(\mathrm{mm})\end{array}$ & $\begin{array}{c}\text { Model } \\
4 \\
(\mathrm{~mm})\end{array}$ \\
\hline Storey 11 & 24.07 & 22.41 & 18.31 & 15.14 & 22.68 & 22.51 & 19.83 & 17.81 \\
\hline Storey 10 & 23.21 & 21.21 & 16.73 & 13.57 & 21.52 & 21.62 & 18.40 & 16.33 \\
\hline Storey 09 & 21.84 & 19.64 & 14.92 & 11.90 & 19.90 & 20.27 & 16.75 & 14.64 \\
\hline Storey 08 & 20.03 & 17.77 & 13.00 & 10.19 & 17.97 & 18.53 & 14.90 & 12.79 \\
\hline Storey 07 & 17.87 & 15.61 & 10.99 & 08.46 & 15.77 & 16.49 & 12.87 & 10.84 \\
\hline Storey 06 & 15.44 & 13.22 & 08.95 & 06.76 & 13.38 & 14.22 & 10.70 & 08.84 \\
\hline Storey 05 & 12.82 & 10.66 & 06.91 & 05.13 & 10.87 & 11.79 & 08.46 & 06.85 \\
\hline Storey 04 & 10.07 & 08.04 & 04.97 & 03.62 & 08.30 & 09.27 & 06.23 & 04.94 \\
\hline Storey 03 & 07.26 & 05.44 & 03.19 & 02.28 & 05.78 & 06.71 & 04.14 & 03.19 \\
\hline Storey 03 & 04.44 & 03.04 & 01.70 & 01.19 & 03.41 & 04.16 & 02.31 & 01.70 \\
\hline Storey 02 & 01.76 & 01.06 & 00.57 & 00.40 & 01.33 & 01.71 & 00.84 & 00.58 \\
\hline Storey 01 & 24.07 & 22.41 & 18.31 & 15.14 & 22.68 & 22.51 & 19.83 & 17.81 \\
\hline
\end{tabular}



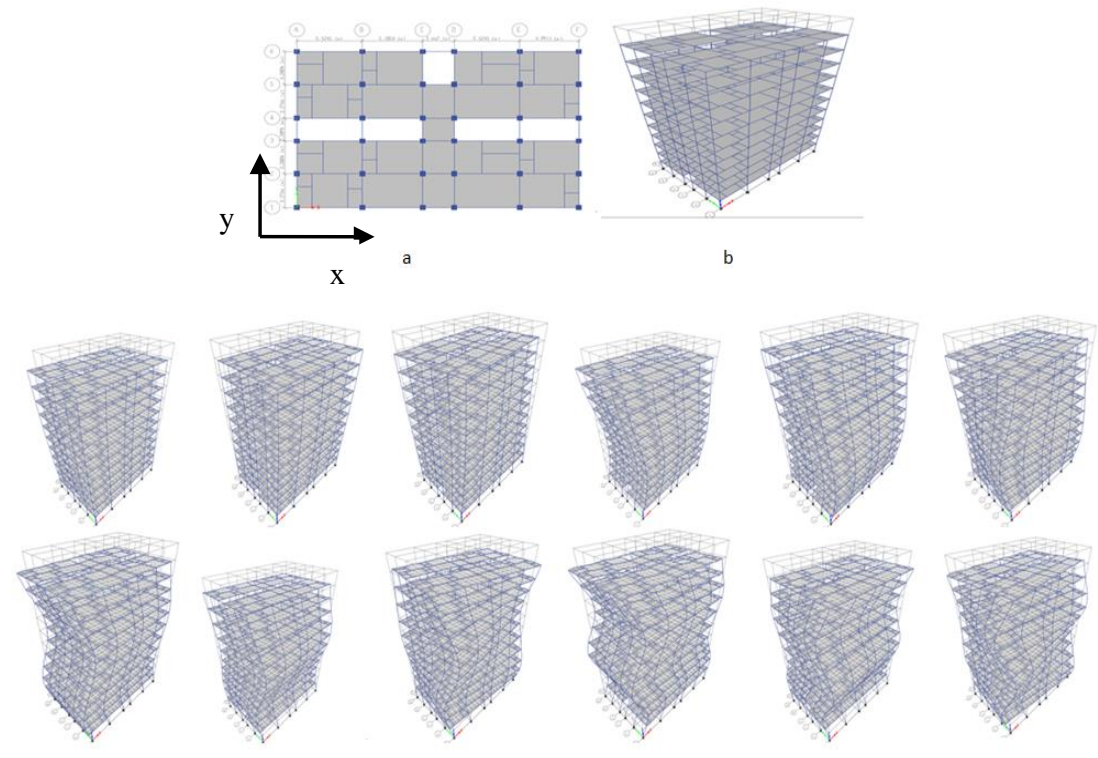

Figure 3. Structure without shear wall, a) Plan, b) 3D View, c) Mode shapes

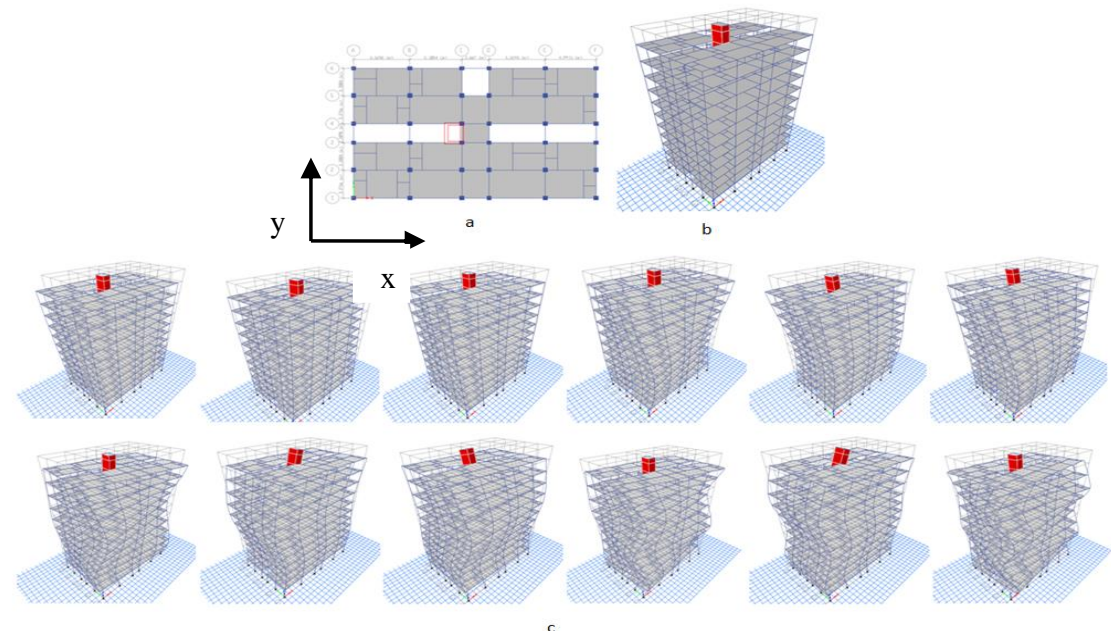

Figure 4. Shear wall at core of the building a) Plan, b) 3D View, c) Mode shapes

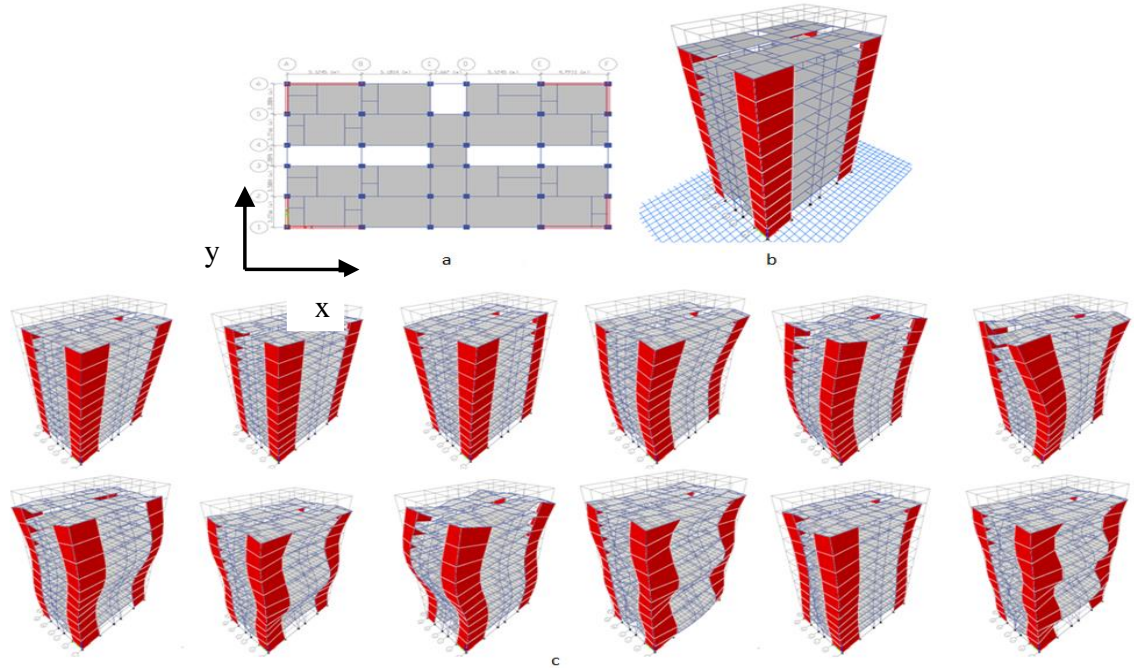

Figure 5. Structure with shear wall located at corners of building (symmetry) a) Plan, b) 3D View, c) Mode shapes 

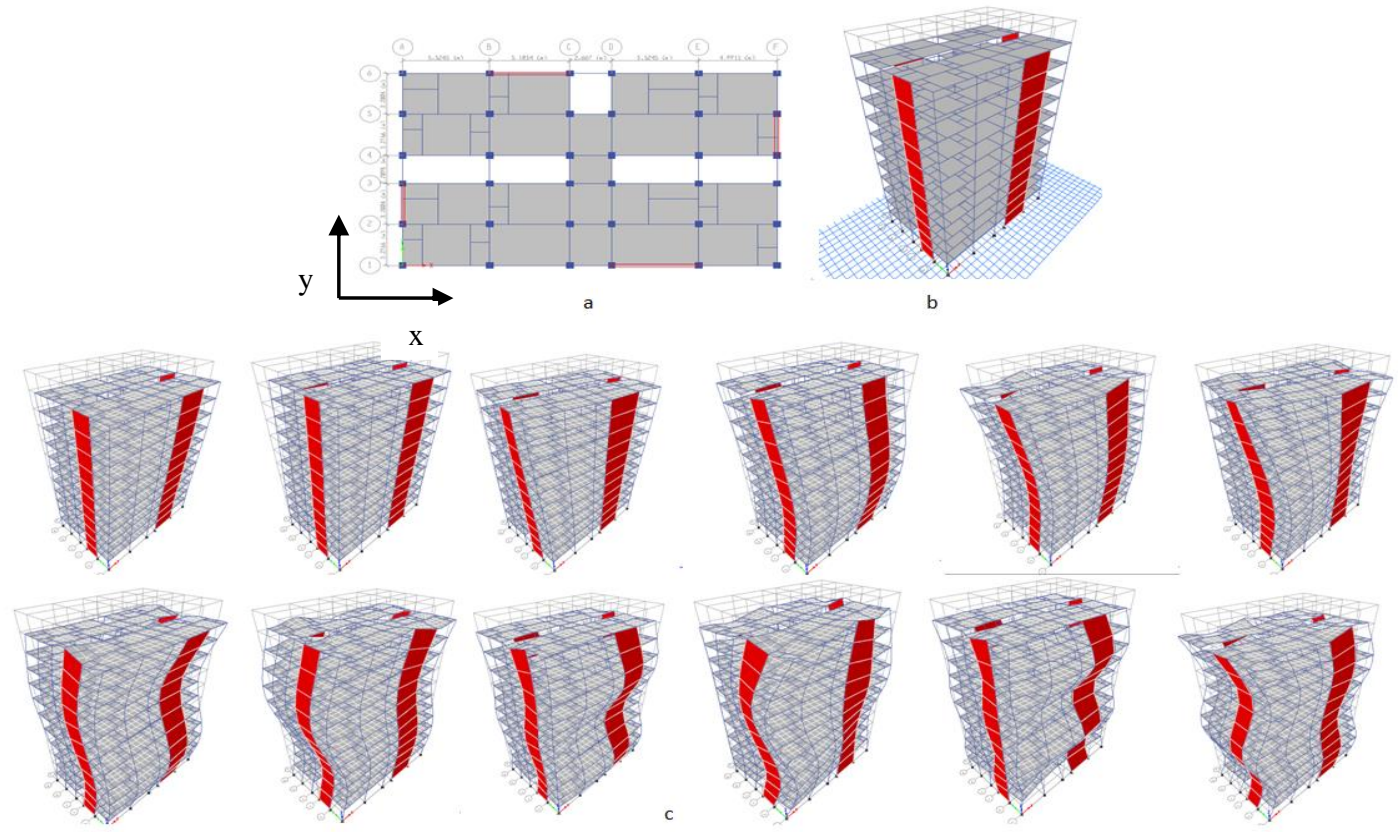

Figure 6. Structure with shear wall at different locations of building (unsymmetry) a) Plan, b) 3D View, c) Mode shapes.

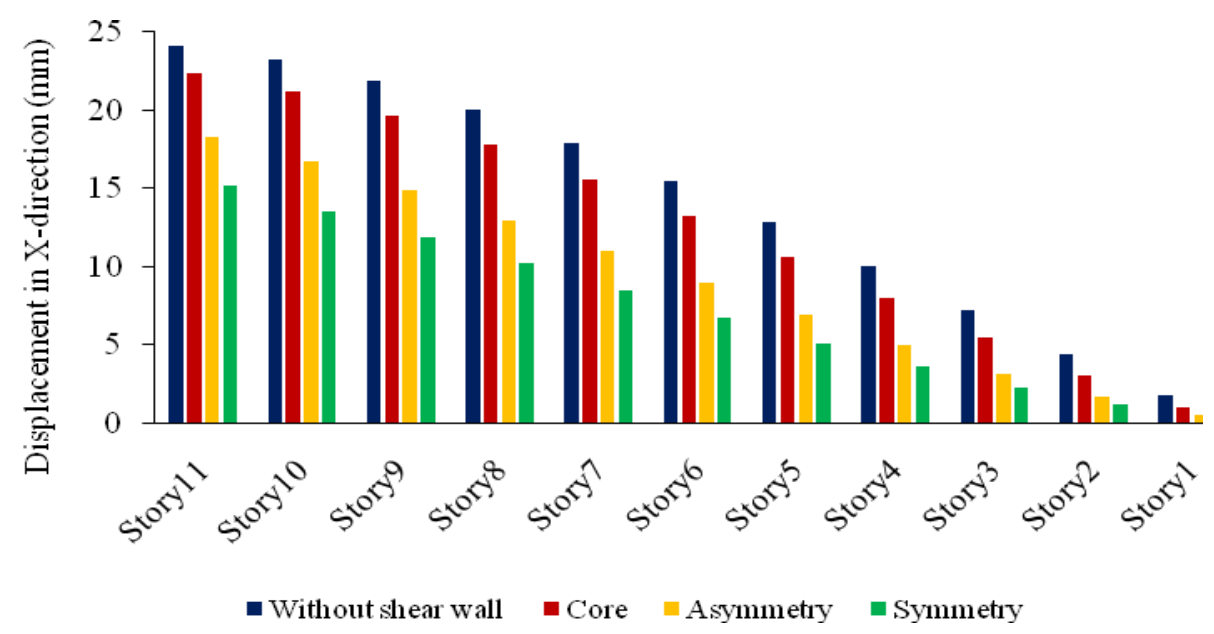

Figure 7. Storey displacements in X-direction

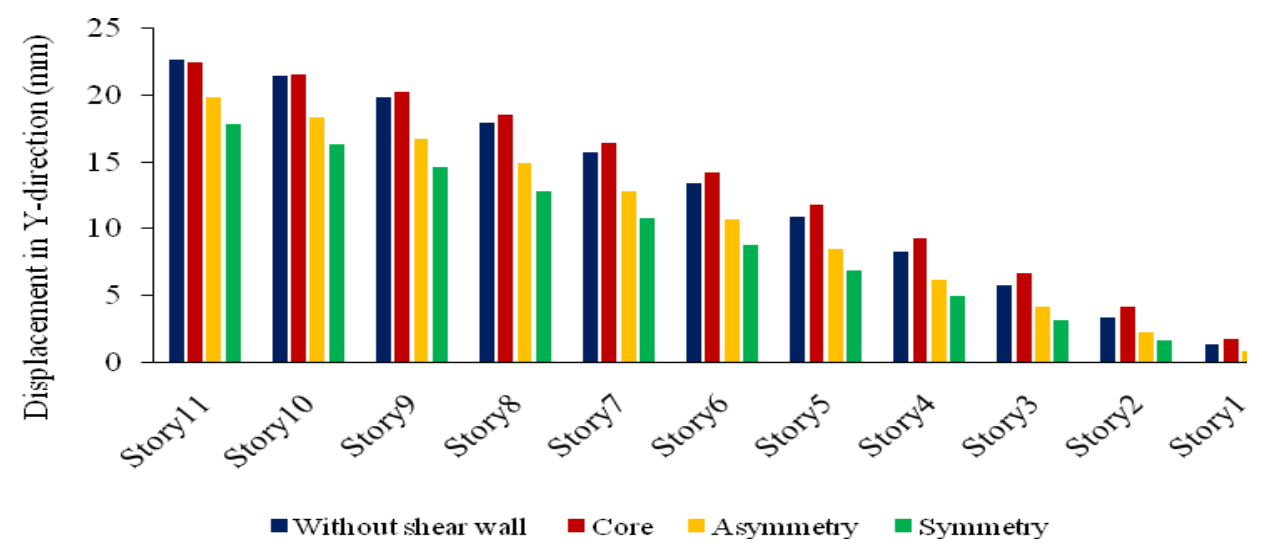

Figure 8. Storey displacements in Y-direction 


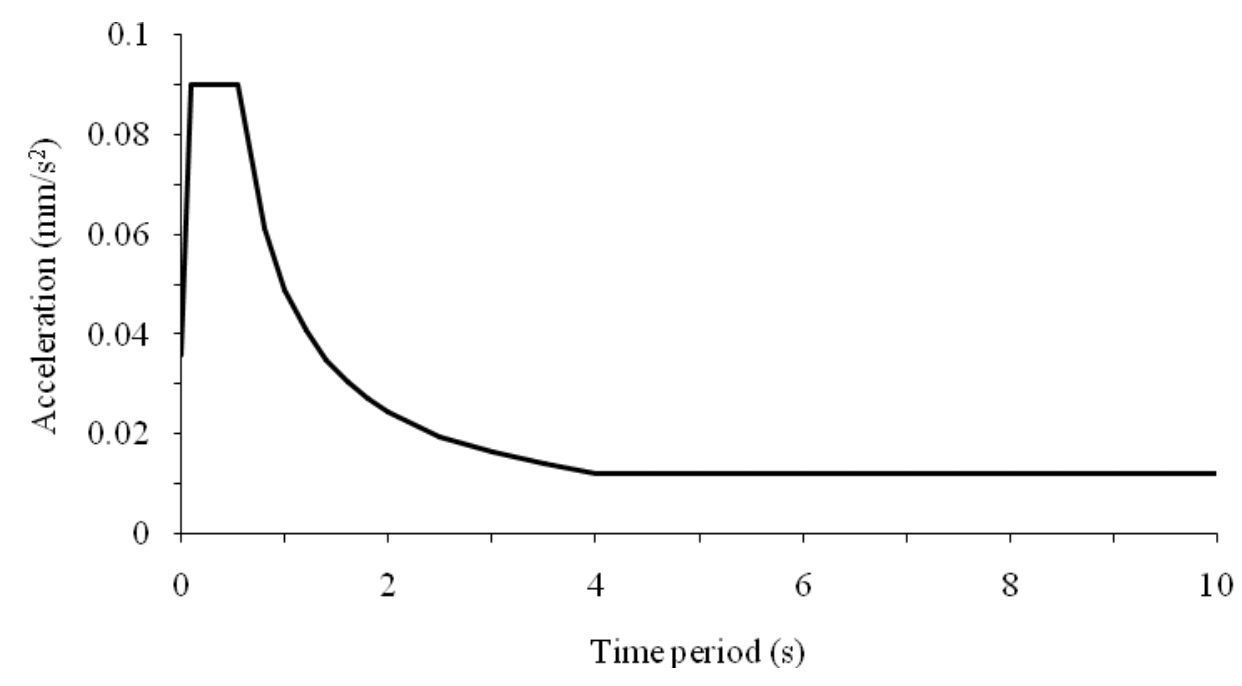

Figure 9. Response spectrum curve

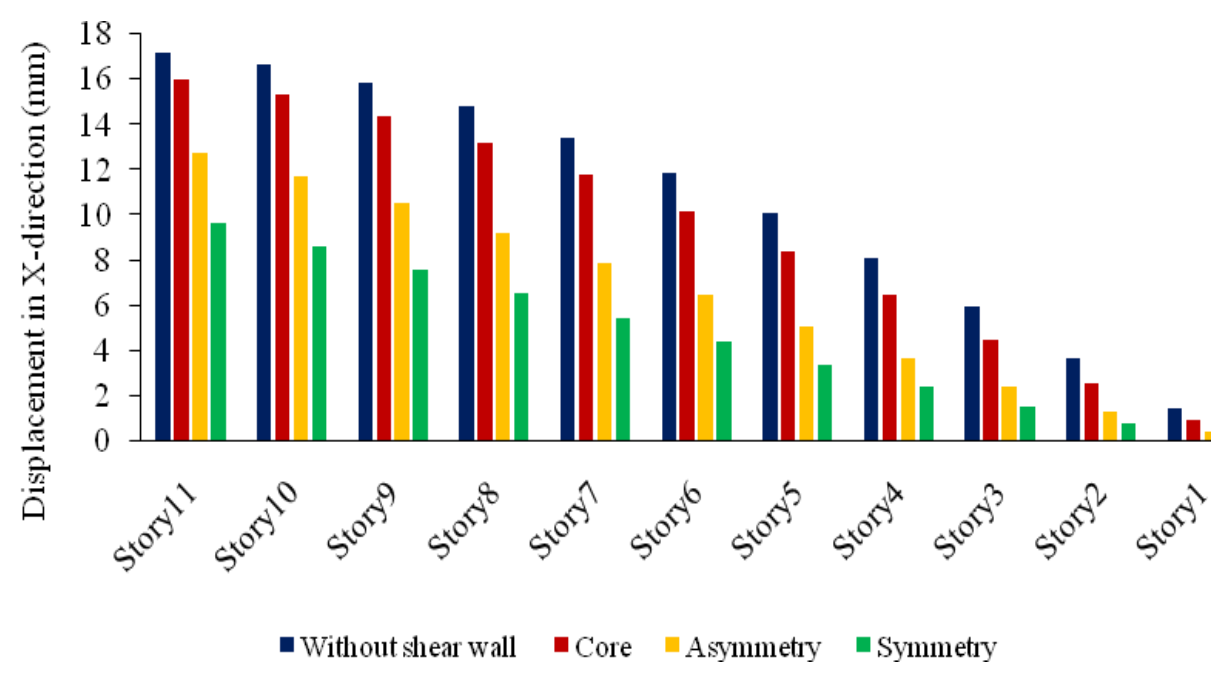

Figure 10. Response spectrum analysis-based displacements in X-direction

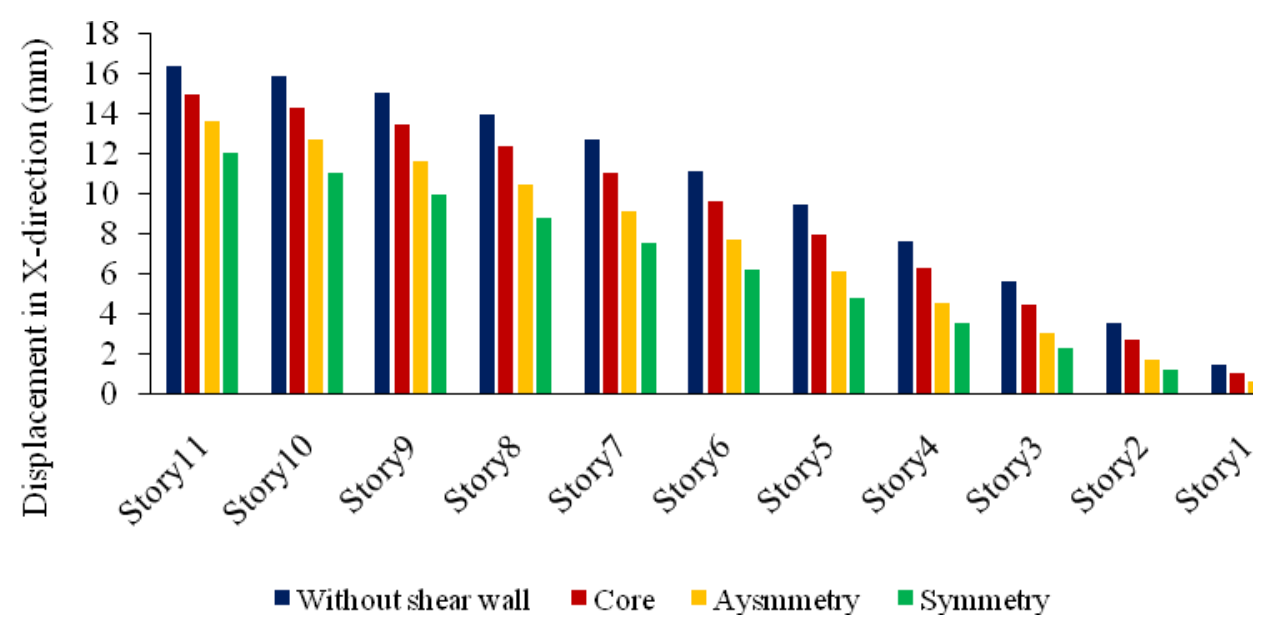

Figure 11. Response spectrum analysis-based displacements in Y-direction 


\section{Conclusion}

Based on the model results the location of shear walls in the outer periphery corner edges of the structure is more suitable and also reduces storey drifts and displacements greater than the structures having shear wall located at other places. In this study it is also observed that the structure with higher natural frequency and a shorter time period tend to suffer high acceleration but smaller displacements.

\section{References}

1. A Murali Krishna and E Arunakanthi. 2014. Optimum Location of Different Shapes of Shear Walls in Unsymmetrical High Rise Buildings" International Journal of Engineering Research \& Technology. 3 (9): 1099-1106. September.

2. A. Mohan, V.Saravana Karthika , J. Ajith, Lenin dhal, M. Tholkapiyan, "Investigation on ultra high strength slurry infiltrated multiscale fibre reinforced concrete", Materials Today : Proceedings, Volume 22, 904-911, 2020.

3. Belsari Sumit Bandopanth and Dilip Budhlani. 2020. Seismic response of structures with single core. International Journal of Trend in Scientific Research and Development. 4 (3): 1131 1136.April.

4. Gopalakrishnan, R., Mohan, A., Sankar, L. P., \& Vijayan, D. S. (2020). Characterisation On Toughness Property Of Self-Compacting Fibre Reinforced Concrete. In Journal of Environmental Protection and Ecology (Vol. 21, Issue 6, pp. 2153-2163).

5. Hamdy H. A and Abd-el-rahim, 2010. Role of shear walls in high rise buildings. Journal of Engineering Sciences, 55(1).March.

6. Dhayachandhran K S, Jothilakshmi M, Tholkapiyan M, Mohan A, "Performance Evaluation and R-Value for Thermally Insulated Wall With Embedding Fluted Sheets", Materials Today : Proceedings, ISSN: 1904-4720, Volume 22, 912-919, 2020.

7. $\mathrm{Hu} \mathrm{H}$ and Nie J. 2013. Deformability analysis of composite shear walls with double steel plates and infill concrete. Journal of Building Structures 34(5): 52-62.

8. R. Gopalakrishnan , VM Sounthararajan , A. Mohan , M. Tholkapiyan, "The strength and durability of flyash and quarry dust light weight foam concrete", Materials Today : Proceedings , Volume 22, 1117-1124, 2020.

9. Lee T. H and Mosalam K. M. 2005. Seismic demand sensitivity of reinforced concrete shear-wall building using FOSM method. Earthquake Engineering \& Structural Dynamics. 34(14):1719-36.

10. M. Tholkapiyan, A.Mohan, Vijayan.D.S, A survey of recent studies on chlorophyll variation in Indian coastal waters, IOP Conf. Series: Materials Science and Engineering 993 (2020) 012041, 16.

11. Lavanya Prabha, S., Gopalakrishnan, M., Neelamegam, M., Development of high-strength nanocementitious composites using copper slag, ACI Materials Journal, 2020, 117(4), pp. 37-46.

12. Mallika.K ., and Nagesh Kumar.G. 2016. Analysis of Shear Wall in High Rise Unsymmetrical Building Using Etabs. International Journal of Innovative Research in Science, Engineering and Technology. 5, (11), November.

13. MD. Maksudul Haque and Md. Hasibulhasan Rahat. 2018. Numerical analysis of high rice RCC buildings with shear walls having opening of different shapes. International Journal of Advances in Mechanical and Civil Engineering. 5(3). June.

14. Lavanya Prabha, S., Dattatreya, J.K., Neelamegam, M., ,Investigation of bolted RPC plate under direct tension, Journal of Structural Engineering (Madras), 2009, 36(5), pp. 333-341

15. Smith B.J., Kurama Y.C and McGinnis M.J. 2013. Behavior of precast concrete shear walls for seismic regions: comparison of hybrid and emulative specimens. Journal of Structural Engineering. 139(11):1917-27.

16. Prabha, S.L., Surendar, M., Neelamegam, M., Experimental investigation of eco-friendly mortar using industrial wastes, Journal of Green Engineering, 2019, 9(4), pp. 626-637

17. Sylviya. B and P. Eswaramoorthi. 2018. Analysis of RCC Building with Shear Walls at Various Locations and In Different Seismic Zones. International Journal of Innovative Technology and Exploring Engineering, 8(2). December. 